\title{
Astroturizam - u traganju za novim prostorima i imaginacijom u turizmu
}

\author{
Aleksandra Krajnović \\ Sveučilište u Zadru, Odjel za ekonomiju, Hrvatska \\ e-mail:akrajnov@unizd.hr
}

SAŽETAK U ovom se radu istražuje pojam i razvoj astroturizma kao novog oblika održivog i odgovornog turizma, koji se ubrzano razvija u mnogim zemljama svijeta, s posebnim osvrtom na certificiranje u astroturizmu. $U$ radu su postavljene dvije istraživačke hipoteze. Prva: postoji uska korelacija između razvoja astroturizma kao novog oblika selektitvnog turizma te jačanja zaštite od svjetlosnog onečišćenja, pri čemu mračno nebo predstavlja osnovni prirodni preduvjet za razvoj ovog oblika turizma. Druga: certificiranje u astroturizmu sve se više razvija na globalnoj i na nacionalnoj razini u nekim zemljama. Ono ima svrhu društvene i marketinške afirmacije astroturizma, ali i senzibilizacije javnosti za astronomiju i problematiku svjetlosnog onečišćenja. Obje su hipoteze u radu potvrđene temeljem kvalitativne komparativne analize triju međunarodnih projekata certifikacije u astroturizmu. U radu je posebno obrađena „Deklaracija o zaštiti noćnog neba i pravu na svjetlost zvijezda“, tzv. La Palma ili Starlight deklaracija iz 2007. godine, kojom je „sve započelo“ i koja je prvi put jasno proklamirala pravo na jasno i mračno, svjetlosno očuvano nebo kao pravo čovječanstva, što je ujedno i godina kada je prvi put javno deklariran pojam astroturizma. Isto tako u radu se daje osvrt i na korake koji su poduzeti u Republici Hrvatskoj u tom smjeru, pri čemu se posebno ističe proglašenje dvaju prirodnih područja u kategoriji Međunarodnog parka tamnoga neba, kao i donošenje pravne regulative o borbi protiv svjetlosnog onečišćenja. No znanstvenici su dokazali da Hrvatska ima značajan potencijal za razvoj astroturizma jer njen geografski prostor još uvijek nije u potpunosti svjetlosno zagađen. Kao znanstveni doprinos rada ističe se doprinos teoretskim okvirima u području astroturizma, potvrđivanje korelacije između zaštite od svjetlosnog onečišćenja i razvoja astroturizma te senzibiliziranje znanstvene i opće javnosti za tu problematiku, posebice za problem svjetlosnog onečišćenja, kao i poticaj za bolju valorizaciju potencijala za razvoj astroturizma u Republici Hrvatskoj na principima održivog razvoja.

Ključne riječi: astroturizam, znanost i turizam, svjetlosno onečišćenje, Starlight deklaracija, certifikati u astroturizmu, park tamnoga neba. 


\section{Siamo materia stellare che medita sulle stelle... (,Mi smo zvjezdana materija koja meditira o zvijezdama...") (Carl Sagan - Cosmos, Astronomitaly)}

\section{Uvod}

Novi društveni i ekonomski uvjeti, a prije svega neodrživost sadašnjeg, dominantno masovnog turizma, kao i aktualne društvene i ekonomske turbulencije, pa i aktualni trenutak pandemije COVID-a 19, svakako će se odraziti na buduća ponašanja i odnose u društvu, kako na lokalnoj tako i na globalnoj razini. Jedna od djelatnosti koja je značajnije zahvaćena aktualnom pandemijom je turizam, koji u ovom kontekstu treba sagledavati ne samo kroz njegova ekonomska obilježja već i kao sveopći društveni fenomen, što je posebno uočljivo u trenutku aktualne krize kroz koju svjetski turizam prolazi. Stoga je ovo pogodan trenutak za nova promišljanja o transformaciji turizma - masovni turizam u saturiranim turističkim destinacijama, koje su iskomercijalizirale i komodificirale svoje brojne autohtone turističke resurse do krajnjih granica, kao i dosadašnje vrijednosti, vjerojatno će se reakturalizirati na nove načine: sve veće značenje dobivat će selektivni oblici turizma, pa i oni koji su ranije bili tržišno slabije vrednovani ili su čak imali karakter (isključivo) tržišne niše. No kako bi se tom procesu transformacije pristupilo na sustavan način, pitanju razvoja novih oblika održivog turizma treba pristupiti dugoročno - strateški te koristeći stakeholderski pristup i različite oblike umrežavanja i suradnje. Takve nove forme turizma trebale bi donijeti veću dobrobit kako turističkim posjetiteljima tako i domicilnom stanovništvu te široj društvenoj zajednici.

Riječ je, dakle, o tome da je nastupio trenutak kada treba identificirati koje su to forme turizma do sada bile "na rubu" - nedovoljno afirmirane, nedovoljno vrednovane te akademski, politički, društveno i ekonomski na marginama. Jedna od takvih formi selektivnog turizma, koja se analizira u ovom radu, je astroturizam.

U radu će se prikazati osnovna obilježja i razvoj astroturizma, kao i smjernice za daljnja istraživanja i praktične implikacije. Premda je riječ o relativno novom obliku selektivnog turizma, pretpostavka je da će se on sve više razvijati jer je u potpunosti u skladu s novim trendovima postindustrijskog (i postdigitalnog?) svijeta, a riječ je o traganju za smislom, introspekciji, imaginaciji, želji za očuvanjem i zaštitom planeta i zajednice, edukaciji i težnji za novim spoznajama. Čini se da je upravo astroturizam jedan od selektivnih oblika turizma koji zadovoljava navedene težnje suvremenog čovjeka, a koji ujedno ostvaruje sinergiju s drugim oblicima turizma te je u skladu $s$ rastućim trendovima i razvojnim pravcima čovječanstva kao što su: sve veća uloga znanosti i tehnologije u suvremenom društvu, značenje edukacije, povratak mašti, težnja za konzervacijom i zaštitom prirodnih i društvenih resursa i slično. 
Zbog kompleksnosti i širine sagledavanja fenomena astroturizma kao relativno nove pojave, koja još nije dobila svoj znanstveni pa ni potpuni praktični okvir, u radu je fokus postavljen na jedan od segmenata koji astroturizam dotiče, ali je, prema nekim autorima, i njegov sastavni dio, a to je ekologija i ekoturizam.

U smislu doticaja s ekologijom, u radu se obrađuje segment ekologije koji je često zanemaren, a to je svjetlosno onečišćenje i njegova veza s astroturizmom. Stoga je prva istraživačka hipoteza ovoga rada sljedeća: borba protiv svjetlosnog onečǐsćenja teče usporedo s razvojem astroturizma, odnosno mračno je nebo conditio sine qua non razvoja astroturizma.

Drugi dio rada odnosi se na sagledavanje astroturizma kao fenomena u turističkom sektoru, pri čemu se istraživanje u ovom radu fokusira na ekološke certifikate koji su vezani za mračno zvjezdano nebo, što je ujedno i ekološka dimenzija, ali i ključni resurs te najvažnija atrakcija za razvoj astroturizma. Obrađuju se tri međunarodna projekta i dimenzije, kriteriji i vrste certifikata koji se dodjeljuju određenim entitetima vezanima uz astroturizam. $U$ tome se ujedno sastoji druga hipoteza rada, koja glasi: certifikacija u astroturizmu bitna je sastavnica tog fenomena. Ti certifikati imaju nekoliko dimenzija, kao što su: upravljanje kvalitetom, marketinški, time ujedno i komunikacijsko-informativni aspekt, znanstveno-edukativni aspekt, a moguće su još neke dimenzije koje je potrebno dodatno istražiti.

U radu su postavljena i sljedeća istraživačka pitanja:

1. Do koje je razine razvijen konceptualni okvir te je li donesena jednoznačna definicija i klasifikacija pojma astroturizma is njime povezanih pojmova?

2. Koji su uvjeti razvoja astroturizma (infrastrukturni, stakeholderski, strateški) te koja su njegova specifična obilježja?

3. Koje su funkcije i područja certificiranja u astroturizmu?

4. Koji su primjeri dobre prakse po pitanju razvoja astroturizma u Republici Hrvatskoj?

\section{Pojam i klasifikacija astroturizma}

Temeljem analize znanstvene literature može se zaključiti da se istraživanje i teorija o astroturizmu značajnije razvijaju tek u posljednjih desetak godina, što dokazuje da je riječ o novom području znanosti i prakse. Pojam astroturizma uveden je u domaću znanstvenu literaturu 1999. godine u radu autora Korlević i Krajnović, gdje ga definiraju kao „selektivni oblik turizma usmjeren na popularizaciju astronomske znanosti i prezentaciju astronomskih znanstvenih otkrića u okviru posjete astronomskim centrima - zvjezdarnicama ili opservatorijima" (Korlević i Krajnović, 1999.:88). Zanimljiva je teza skupine afričkih autora koji navode da ,astroturizam nudi noćno nebo kao proizvod i uslugu namijenjenu prodaji turistima" (Kulvinder i sur., 2020.:20). Herrero (2019.) dokazuje da ne postoji objedinjena definicija astroturizma te da se definicija 
tog pojma razlikuje od autora do autora. On navodi: „Različiti autori donose različite definicije pojma astroturizma, što dovodi do kontroverzne točke u kojoj se analiza situacije ne može izvršiti dok se prethodno ne donese jasna definicija astroturizma [...]“ i nastavlja: „[...] pojmovi astroturizam i astrodestinacija nisu nikada definirani, što stvara značajnu prazninu koju treba popuniti“ (Herrero, 2019.:5).

Caballero-Sánchez i suradnici (2019.) u svom radu ističu i druge sinonime pojma astroturizma, i to: nebeski turizam (engl. celestial tourism), astronomski turizam (engl. astronomical tourism) ili, rjeđe, zvjezdani turizam (engl. star tourism). Oni navode da se pojam odnosi na „posjete mjestima gdje se nebeski fenomeni mogu jasno promatrati“ (Caballero-Sánchez i sur.: 2019.:2). Ovdje je zanimljivo spomenuti i srodne pojmove, primjerice „astronomija golim okom“, kojim Tadić (2016.) definira „astroturizam manjih razmjera", te pojam dark-sky turizma, kojime autori Kunjaya, Sukmaraga i Arsono (2019.) praktički poistovjećuju astroturizam s mračnim nebom kao turističkim resursom. Prikupivši spoznaje o konceptualnom okviru astroturizma, Herrero donosi vlastitu, objedinjenu definiciju koja glasi: „Astroturizam je zabavna aktivnost unutar grane ekoturizma i znanstvenog turizma, koja je zamišljena kao aktivnost planiranja putovanja, samog putovanja i boravka na vrlo specifičnom mjestima (astrodestinacijama) s vrlo konkretnim obilježjima [koja omogućuju] nova i različita astronomska iskustva koja nisu ostvariva u mjestu boravka." (Herrero, 2019.:7). Uočava se, dakle, konceptualni istraživački jaz vezan uz pojam astroturizma i astroturističke destinacije. U širem kontekstu, astroturizam se smatra održivom i ekoturističkom praksom, budući da je nužno povezan sa zaštitom noćnog neba (Herrero, 2019.).

Kao što još nije donesena jednoznačna definicija pojma astroturizma, tako u znanstvenoj teoriji nije donesena ni jedinstvena klasifikacija tog pojma. Mnogi autori astroturizam svrstavaju u grupaciju svemirskog turizma (Cater, 2010. i 2019.; Toivonen, 2017.), no autori su jednoglasni u stavu da se radi o podskupini ekološkog turizma (Weaver, 2011.; Najafabadi, 2012.; Tobin i Dunne, 2017.; Caballero-Sánchez i sur., 2019.). Brojni autori uočavaju vezu i konvergenciju pojma astroturizma s ruralnim turizmom (Van Wyk-Jacobs, 2018.; Yazar, 2018.) te kulturnim turizmom (Holbrook, Medupe i Urama, 2008.) smatrajući da astroturizam treba biti komplementarni oblik turizma u destinaciji na čiji imidž značajno utječe (Ingle, 2010.; Fayos-Solá, Marin i Jafari, 2014.; Belij i Tadić, 2015.; Jiwaji, 2016.; Matos, 2017.; Kunjaya i sur., 2019.; Soleimani i sur., 2019.). Zanimljiva je teza i o konvergenciji ka storytellingu i turizmu priča i legendi, što Kulvinder i sur. (2020.) označavaju interpolacijom etnoastronomije u kontekst astroturizma. Od afričkih autora ovdje treba spomenuti i već navedene autore Kunjaya i sur. (2019.), koji u svom radu ističu značajnu vezu između kulture i astroturizma.

Kada je riječ o ekologiji, autori su jednoglasni u tezi da je nužan uvjet za razvoj astroturizma mračno nebo, odnosno nebo koje nije svjetlosno onečišćeno (Priyatikando i sur., 2019.). U Republici Hrvatskoj jedan od prvih zagovaratelja mračnog neba i borbe protiv svjetlosnog onečišćenja bio je renomirani astronom i edukator prof. Korado 
Korlević, voditelj svjetski poznate Zvjezdarnice Višnjan ${ }^{1}$, a slijedili su ga i drugi hrvatski astronomi. U ovom radu se obrađuje upravo ta tematika, s posebnim osvrtom na tzv. Parkove tamnoga neba (Dark Sky parkove), o čemu su pisali brojni autori navodeći uspješne studije slučaja u brojnim zemljama u svijetu. Tako, primjerice, Welch i Dick 2012. prikazuju pregled najpoznatijih svjetskih Dark-Sky parkova, dok drugi autori obrađuju slučajeve u različitim zemljama: Austin i sur. (2012.) te Hearnshaw (2015.) - Novi Zeland; Collison i Poe (2013.) - SAD; Tadić (2016.) - Srbija; Pisarek, GargałaPolar i Dudek (2017.) - Poljska; Tobin i Dunne (2017.) - Irska; Kunjaya i sur. (2019.) - Indonezija; Honorato i Violin (2019.) - Brazil; Jacobs, Du Preez i Fairer-Wessels (2020.) - Južnoafrička Republika; Kulvinder i sur. (2020.) - Tanzanija i Kenija itd.

\section{U obrani noćnog neba - problem svjetlosnog onečišćenja i Starlight deklaracija}

Prema definiciji IDA-e - Međunarodnog udruženja za zaštitu tamnoga neba (International Dark-Sky Association), svjetlosno onečišćenje (engl. light polution) odnosi se na „neodgovarajuće korištenje noćnog umjetnog svjetla - riječ je o zagađenju okoliša koje šteti našem planetu $i$ „oduzima nam priliku da iskusimo čudesne ljepote prirodnog noćnog neba." ${ }^{2}$

IDA definira svjetlosno onečišćenje kao „svaki štetni efekt umjetnoga svjetla, uključujući povećanje svjetline noćnoga neba, zasljepljivanje, osvjetljivanje izvan područja koja je potrebno osvijetliti, prekomjerno osvjetljivanje, smanjenu vidljivost noću i rasipanje svjetlosne energije“(IDA). Ponekad se koristi i termin „rasipanje svjetla“ (engl. light spill). Zakon o zaštiti okoliša ovako definira svjetlosno onečišćenje: „Svjetlosno je onečišćenje promjena razine prirodne svjetlosti u noćnim uvjetima uzrokovana unošenjem svjetlosti proizvedene ljudskim djelovanjem“" (Andreić i sur., 2010.:757.).

Pitanje svjetlosnog onečišćenja u velikoj mjeri nadilazi područje astroturizma, riječ je o važnom ekološkom i javno-zdravstvenom problemu, koji još uvijek u javnosti nije dovoljno poznat, a nije dovoljno istraženo ni do koje je mjere ta problematika uključena u strategije održivog razvoja, pravnu regulativu, nastavne kurikulume u školama i na fakultetima i slično. Primjerice, među 17 globalnih ciljeva održivog razvoja $\mathrm{UN}-\mathrm{a}^{3}$ ne nalazi se izričito naznačena problematika svjetlosnog onečišćenja, što bi svakako trebalo uvrstiti u ovu svjetsku Globalnu Agendu održivog razvoja kao zasebni cilj.

U tom smislu čini se da su inicijative o svjetlosnom onečišćenju svedene na margine. Jedna od najvažnijih inicijativa na globalnoj razini odnosi se na tzv. Starlight deklara-

\footnotetext{
1 Detaljnije na: www.astro.hr

2 www.darksky.org, prijevod autora

3 Dostupno na: https://sdgs.un.org/goals
} 
ciju, preciznije: Starlight Declaration: in Defense of the Night Sky and the Right to Starlight ${ }^{4}$, nazvanu i Deklaracijom iz La Palme (La Palma Declaration), koja je donesena pod motom: „U obrani noćnog neba i prava na svjetlost zvijezda“. Deklaraciju su donijeli sudionici Međunarodne konferencije u obrani kvalitete noćnog neba i prava na promatranje zvijezda (International Conference in Defence of the Quality of the Night Sky and the Right to Observe the Stars), koja je održana u španjolskoj La Palmi, na Kanarskim otocima, 19. i 20. travnja 2007. godine. Pored zanimljivog, stilski i umjetnički oblikovanog amblema Deklaracije koji simbolizira čisto, svjetlosno nezagađeno zvjezdano nebo (slika 1), Deklaracija ima i svoj slogan, koji glasi: „Zvjezdano nebo naša zajednička baština“" (Starlight - a Common Heritage).

Temelj za donošenje Starlight deklaracije bila je svijest o tome da je, kako se u njoj navodi, ,pogled na zvjezdano nebo trajna inspiracija čovječanstva te je promatranje neba oduvijek predstavljalo esencijalni element u razvoju kultura i civilizacija, a danas i kroz povijest kontemplacija o Svemiru podržala je brojna znanstvena i tehnološka otkrića i time potaknula njihov razvoj“ (Deklaracija iz La Palme, 2007.). U uvodnom dijelu Deklaracije naglašeno je i kako je „čovječanstvo oduvijek promatralo Svemir zato da interpretira i razumije fizičke zakone koji upravljaju Svemirom [...] te da interes za astronomiju ima duboke implikacije na znanost, filozofiju, kulturu i na opći koncept Svemira" (Deklaracija iz La Palme, 2007.). Autori Deklaracije naglašavaju da je kvaliteta noćnog neba, a samim time i kapacitet promatranja zvijezda i drugih nebeskih tijela u pojedinim dijelovima svijeta značajno ugrožen, čime se nepovratno gubi taj značajni kulturni, znanstveni i prirodni resurs - svjetlosno čisto nebo. ${ }^{5}$

Slika 1.

Amblem i slogan Starlight (La Palma) deklaracije

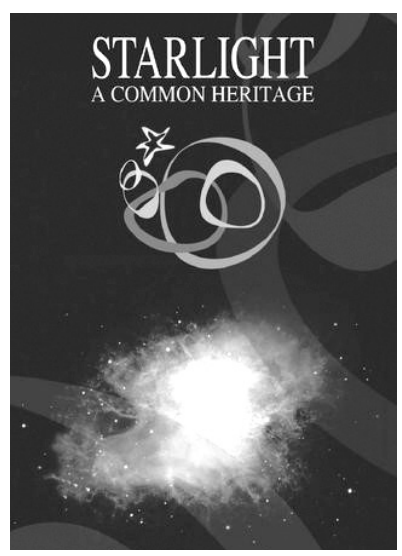

Izvor: https://issuu.com/pubcipriano/docs/starlightcommonheritage

\footnotetext{
${ }^{4}$ Dostupno na: https://fundacionstarlight.org/en/section/starlight-stellar-parks/301.html

5 http://www.archeoastronomy.org/downloads/starlightdeclarationc.pdf
} 
Počeci organizirane brige o svjetlosno nezagađenom nebu datiraju još iz 1992. godine, kada je na Konferenciji u Riju proklamirana nužnost obrane „integralne i međuovisne prirode Zemlje“, koja uključuje i dimenziju noćnog neba i kvalitete atmosfere. Kasnije je ta ideja ugrađena u osnovne principe već spomenute Deklaracije iz La Palme, u kojoj se navodi da se čisto nebo uklapa u koncept „nekontaminiranog i 'neoštećenog' planeta Zemlje, što treba predstavljati temelj za ljudsku povijest i kulturu te socijalnu povezanost ljudi, ali i u smislu očuvanja planeta za buduće generacije“ (Deklaracija iz La Palme, 2007.). U Deklaraciji se nadalje ističe da je čisto nebo značajan segment održivog razvoja „koji je neodjeljiv od prirode, ali i razvoja društva i cijelog čovječanstva, te da je to ujedno i resurs koji ima velikog utjecaja na očuvanje kulturnih različitosti, biološke raznolikosti, krajolika, ali i konzervacije kulturne baštine, kao i značajnu ulogu u borbi protiv klimatskih promjena. [...] Zbog svega toga, očuvanje nezagađenog neba donosi znanstvene, kulturne, edukativne, okolišne, sigurnosne učinke, kao i učinke u smislu očuvanja energije“ (Deklaracija iz La Palme, 2007.).

Deklaracija predstavlja svojevrsni apel svijetu (međunarodnoj zajednici), a posebno vladama i drugim javnim entitetima, donositeljima odluka i strategija, privatnim organizacijama i institucijama u znanosti i kulturi, kao i pojedinim građanima, da se pridržavaju deset u njoj navedenih principa. Slijedi izvod iz teksta Deklaracije o deset ciljeva koje postavlja:

1. Nezagađeno noćno nebo mora biti neotuđivo pravo čovječanstva, ekvivalent drugim okolišnim, društvenim i kulturnim pravima.

2. Progresivna degradacija noćnog neba mora se smatrati prijetećim rizikom kojemu se treba suprotstaviti.

3. S obzirom na to da se noćno smatra „živim dijelom naše baštine“, konzervacija, zaštita i revalorizacija prirodne i kulturne baštine povezane s noćnim krajolikom i opservacijom Svemira predstavlja primarnu priliku i obavezu za zajedničku zaštitu kvalitete života stanovnika Zemlje.

4. Adekvatan pristup znanju i edukacija ključne su aktivnosti u integraciji znanosti u kulturu, u smislu diseminacije astronomije i znanstvenih i kulturnih vrijednosti povezanih s kontemplacijom o Svemiru, u cilju svekolikog razvoja čovječanstva.

5. Negativni efekti svjetlosne emisije i rastuće agresivno širenje umjetnog osvjetljenja $\mathrm{u}$ atmosferu donose negativne učinke na brojne žive vrste, habitat i ekosustave. Kontrola umjetnog osvjetljenja mora biti temeljni element politike zaštite prirode i biti implementirana u strategije zaštite na svim razinama.

6. Svjesni činjenice da je zvjezdano nebo sastavni dio krajolika, uključujući i urbane krajolike, javne politike trebaju implementirati standarde zaštite kvalitete noćnog neba, čime će omogućiti opće pravo na kontemplaciju i promatranje neba.

7. Važno je promovirati inteligentno korištenje umjetne rasvjete koja minimizira svjetlosno onečišćenje i sprječava agresivni vizualni utjecaj na ljudsko zdravlje i zdravlje biljaka i životinja. [...] Ova politika treba se implementirati u sustave mjerenja svjetlosnog onečišćenja, kako na nebu tako i sa zemlje, što predstavlja važan segment borbe protiv svjetlosnog onečišćenja. 
8. Područja koja trebaju biti pod posebnom zaštitom su očuvana područja za astronomske opservacije. Ona imaju izuzetno značenje za znanstveni i tehnološki razvoj čovječanstva, a ujedno predstavljaju i svjetski značajan resurs.

9. U očuvanju kvalitete noćnog neba. „Odgovorni turizam može i mora uzeti «u svoje ruke` noćno nebo kao resurs koji treba zaštititi i valorizirati u svakoj destinaciji“. „Kreirajući nove turističke proizvode zasnovane na opservaciji Svemira i nebeskih fenomena [turizam] otvara neograničene mogućnosti za kooperaciju između dionika u turizmu, lokalne zajednice i znanstvenih institucija“.

10. Zaštićena područja prema drugim osnovama (prirodnim, kulturnim i slično) trebaju uključiti valorizaciju kvalitete noćnog neba u svoju misiju zaštite. ${ }^{6}$

Može se uočiti da je problematika zaštite i implementacije politike zaštite od svjetlosnog onečišćenja implementirana u svih deset ciljeva Deklaracije.

\section{Slika 2.}

Svjetlosno onečišćenje u Europi 2001. godine

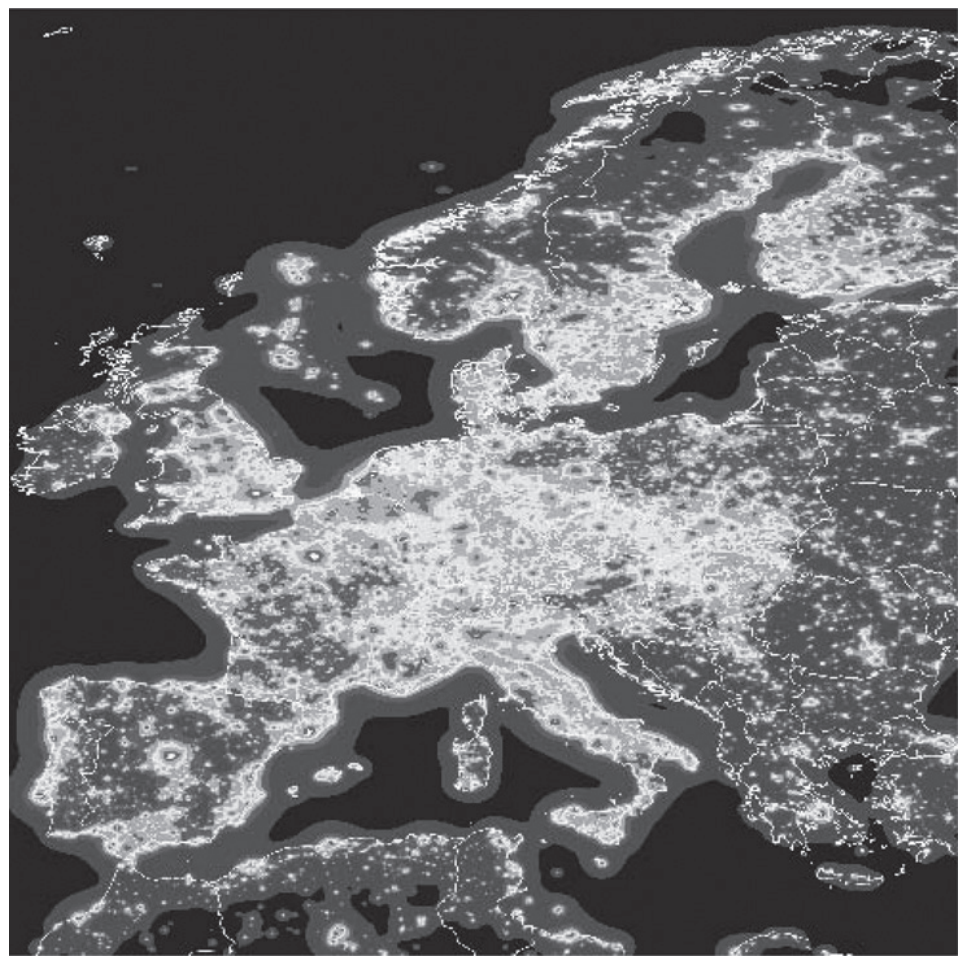

Izvor: P. Cinzano, F. Falchi, C. D. Elvidge (2001). The First World Atlas of the Artificial Night Sky Brightness, Monthly Notices of the Royal Astronomical Society, 328, 3, 689-707, https://doi.org/10.1046/ j.1365-8711.2001.04882.x

\footnotetext{
${ }^{6}$ http://www.darkskiesawareness.org/defense-declaration.php
} 
Slika 3.

Razina svjetlosnog onečišćenja u Republici Hrvatskoj i Italiji - usporedba

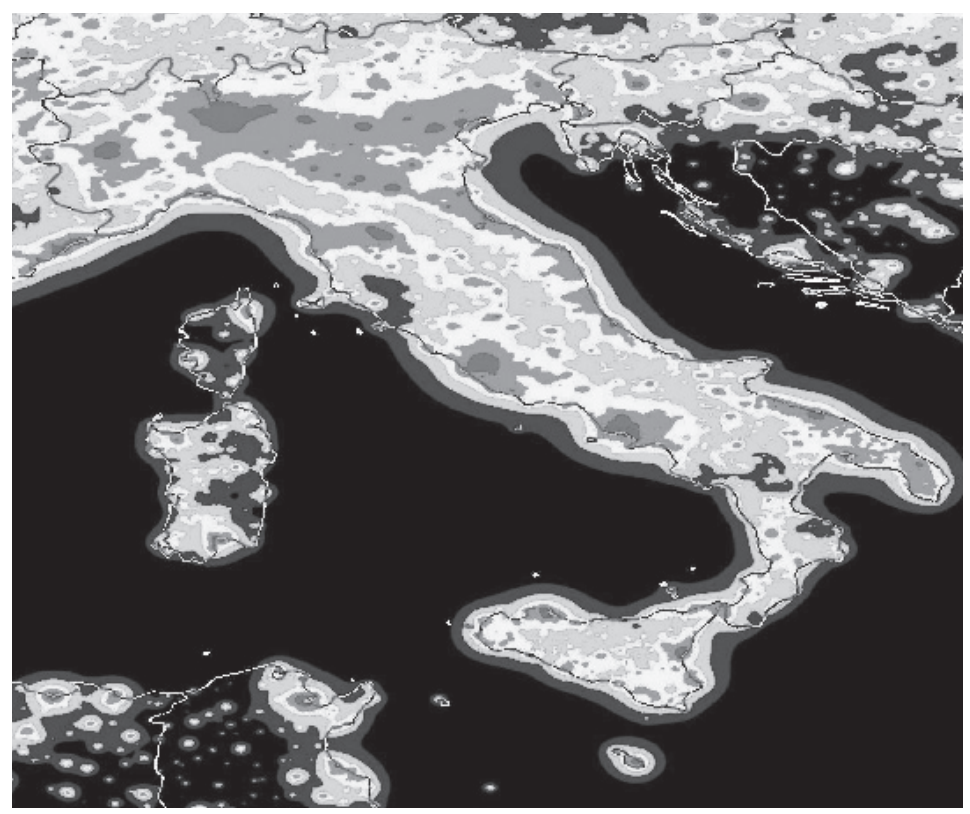

Izvor: World atlas of the artificial night sky brightness, https://tinyurl.com/yxoqehof

Napomena: Detaljniji kartografski prikazi svjetlosnog zagađenja u Republici Hrvatskoj dostupni su u radu: Andreić i sur. (2011). Svjetlosno onečišćenje u Republici Hrvatskoj, Gradevinar, 63, 8, 757-764.

\section{Rezultati istraživanja - prikaz triju međunarodnih projekata}

Slijedi prikaz triju odabranih međunarodnih projekata certifikacije u astroturizmu. U budućim istraživanjima bilo bi dobro analizu proširiti i na druge studije slučaja, što je ujedno i glavno ograničenje ovoga istraživanja.

Slučajevi koji se prikazuju u analizi su sljedeći:

1. IDA certifikati

2. Certifikati kvalitete u astroturizmu IAC-a - IAC Astrotourism Quality Certificate

3. Starlight turističke destinacije u projektu Astronomitaly - Astronomitaly Starlight Tourist Destination, čija certifikacija ima naglašeno marketinško, ali i javno i društveno značenje.

Ciljevi analize bili su izdvojiti nekoliko međunarodnih projekata certifikacije destinacija i proizvoda u astroturizmu, utvrditi koji su kriteriji i uvjeti za certifikaciju, kao i koji su entiteti u astroturizmu koji su podložni certifikaciji. 


\subsection{Djelovanje IDA-e i IDA certifikati}

Međunarodna organizacija za mračno nebo - The International Dark-Sky Association (IDA) vodeća je svjetska organizacija u borbi protiv svjetlosnog onečišćenja. Spominje se i u smjernicama Deklaracije iz La Palme kroz jedan od ciljeva, koji glasi: „Jačati kooperaciju i zajedničku potporu s inicijativama i organizacijama uključenima u konzervaciju mračnog neba, posebno s IDA-om“ (Deklaracija iz La Palme, 2007.:8).

IDA je osnovana 1988. godine i „posvećena je zaštiti noćnog neba za sadašnje i buduće generacije“. Misija IDA-e konzervacija je i zaštita noćnog okoliša (engl. nighttime environment) i naše baštine tamnog neba kroz okolišno odgovornu javnu rasvjetu. ${ }^{7}$

Ciljevi IDA-e su:

- zalagati se za zaštitu noćnog neba

- educirati javnost i donositelje politike o važnosti zaštite noćnog neba

- promovirati okolišno odgovornu javnu rasvjetu

- osnažiti javnost omogućivši im alate i resurse koji će im „pomoći vratiti noć“. ${ }^{8}$

U borbi protiv svjetlosnog onečišćenja IDA surađuje s općom javnošću, lokalnom samoupravom, zakonodavnom vlasti, proizvođačima rasvjetne opreme, upravama zaštićenih prirodnih područja te sličnim organizacijama s ciljem osiguravanja implementacije pametnih rješenja vanjske rasvjete i drugih oblika zaštite. Značajne su i njihove aktivnosti na području edukacije i informiranja, prvenstveno u SAD-u, ali i diljem svijeta.

Među značajnije programe IDA-e spada i tzv. Međunarodni program zaštite područja mračnog neba - The International Dark Sky Places Program (IDSP). Riječ je o programu konzervacije, a ujedno i certifikacije, osnovanom 2001. godine, a koji ima za cilj ohrabriti lokalne zajednice i zaštićena područja diljem svijeta u očuvanju i zaštiti „područja tamnoga neba" (engl. Dark sites) kroz odgovornu politiku javne rasvjete i javnu edukaciju. Certifikacija IDA-e odnosi se na sljedeće kategorije: Međunarodne zajednice tamnoga neba (International Dark Sky Communities), Međunarodni parkovi tamnoga neba (International Dark Sky Parks), Međunarodni rezervati tamnoga neba (International Darks Sky Reserves), Međunarodni sanktuariji tamnoga neba (International Dark Sky Sanctuaries), Urbana područja noćnoga neba (Urban Night Sky Places) i Istaknuta područja Dark-sky friendly razvoja (Dark Sky Friendly Developments of Distinction).

Lokalne zajednice koje prihvate standarde zaštite i konzervacije tamnoga neba i implementiraju kvalitetnu javnu rasvjetu koja svjetlosno ne onečišćuje okoliš te o tome

\footnotetext{
${ }^{7}$ https://www.darksky.org

8 Ibid.
} 
kvalitetno educiraju javnost, dobivaju epitet Međunarodne zajednice tamnoga neba (International Dark Sky Communities). Do sada je dodijeljeno 25 takvih certifikata.

Međunarodni parkovi tamnoga neba (International Dark Sky Parks) javna su ili privatna područja koja su pod režimom zaštite prirode a implementiraju održivu javnu rasvjetu i nude tzv. programe tamnog neba (engl. dark sky programs) za posjetitelje.

Međunarodni rezervati tamnoga neba (International Darks Sky Reserves) sastoje se od tamne, „središnje“ zone okružene okolnom zonom koja se kontrolira na način da se štiti tamni središnji dio rezervata.

Međunarodni „sanktuariji“9 tamnoga neba (International Dark Sky Sanctuaries) geografski su najizoliranija, i često najmračnija, područja na svijetu, čije je stanje konzervacije najosjetljivije. Najčešće ne zadovoljavaju uvjete za uvrštenje u gore navedene kategorije, no značajna su zbog toga što u njihovom okruženju gotovo i nema rizika i prijetnje svjetlosnog onečišćenja, pa su to lokacije iznimne kvalitete noćnoga neba koju treba dugoročno sačuvati. Često nemaju osiguran kvalitetan javni pristup. U svijetu ih trenutno ima 11.

Urbana područja noćnoga neba (Urban Night Sky Places) područja su u blizini ili okružena urbanim okruženjem, čije planiranje i dizajn aktivno promovira autentično iskustvo noćnog neba okruženo noćnom javnom rasvjetom. Cilj je ove kategorije omogućiti dobivanje certifikata onim (u pravilu urbanim) područjima tamnoga neba koji drugačije ne bi dobili certifikaciju jer ne zadovoljavaju uvjete za ranije navedene kategorije, a, pored konzervacijske, imaju i iznimnu promocijsku vrijednost u popularizaciji značenja tamnoga neba. To mogu biti gradski parkovi, otvoreni prostori u gradu ili njegovoj periferiji te druge slične lokacije pogodne za promatranje neba. Trenutno je dodijeljen jedan takav certifikat.

Kategorija Istaknutih područja Dark-sky friendly razvoja (Dark Sky Friendly Developments of Distinction) dodjeljuje se zajednicama - gradovima ili područjima - koje su u svoje strateške planove implementirale politiku zaštite od svjetlosnog onečišćenja i aktivno je provode te promoviraju prirodnije noćno nebo, ali nisu dostigle standarde potrebne za uvrštenje u ranije navedene kategorije. Trenutno ih ima četiri i sve su na području SAD-a.

U sklopu programa certifikacije IDA surađuje s tijelima zaduženima za upravljanje certificiranim područjima kroz promociju njihovih aktivnosti, posebice kroz komuni-

9 U budućim znanstvenim raspravama trebalo bi preispitati opravdanost i preciznost upotrebe izraza „sanktuarij“ - utočište u ovom kontekstu, odnosno definirati adekvatniji prijevod, ali i raspraviti o adekvatnom prijevodu i drugih kategorija ove i sličnih certifikacija. 
kaciju s medijima, ključnim dionicima, komunikaciju na društvenim mrežama i drugo. Kako navode na internetskoj stranici IDA-e, certifikati međunarodnih područja tamnoga neba (International Dark Sky Place - IDSP) „pomažu učvršćenju vidljivosti certificiranih lokacija i jačaju razvoj turizma i lokalne ekonomije “. ${ }^{10}$ Prema podacima IDA-e, u veljači 2020. godine certifikate iz programa IDSP dobilo je više od 130 područja u svijetu. Na internetskoj stranici IDA-e www.darksky.org može se vidjeti njihova lokacija i geografski raspored na interaktivnoj mapi.

Kada je riječ o zastupljenosti i atraktivnosti područja certificiranih od IDA-e, posebno se ističu Međunarodni parkovi tamnog neba, koji se najčešće i valoriziraju kroz astroturizam. Već se u IDA-inoj definiciji tog certifikata ističe da je to „područje koje sadrži iznimnu i specifičnu kvalitetu zvjezdanog neba i noćni okoliš koji je zaštićen na poseban način zbog svoj znanstvenog, prirodnog, edukacijskog, kulturnog i/ili javnog značenja."11 Premda područje može biti u javnom ili privatnom vlasništvu, treba imati osiguran stalni javni pristup. Trenutno u svijetu ima 79 takvih parkova, od čega dva u Hrvatskoj. ${ }^{12}$

\subsubsection{Prva područja s certifikatom Međunarodnog parka tamnog neba u Republici Hrvatskoj}

Na internetskoj stranici IDA-e navedeno je da je Zaštićeno područje prirode Petrova gora - Biljeg dobilo certifikat Međunarodnog parka tamnoga neba, što je ujedno prvi takav park u Hrvatskoj. Petrova gora jedan je od najljepših i najbolje očuvanih gorskih šumskih krajobraza Republike Hrvatske. Zbog iznimne krajobrazne i biološke vrijednosti područje Petrova gora - Biljeg u središnjem dijelu Petrove gore zaštićeno je 1969. godine u kategoriji značajnog krajobraza. ${ }^{13}$ Značajni krajobraz Petrova gora i Biljeg prostire kroz dvije županije (Karlovačka i Sisačko-moslavačka županija) i tri općine (Vojnić, Gvozd i Topusko). ${ }^{14}$ Prema podacima s internetske stranice Astronomskog društva Beskraj, službeno proglašenje bilo je 17. lipnja 2019. godine. ${ }^{15}$

$\mathrm{Na}$ internetskoj stranici IDA-e ističu da je Petrova gora poznata po svom „predivnom zvjezdanom nebu, relativno blizu Zagreba, glavnog grada Hrvatske“, što je čini poseb-

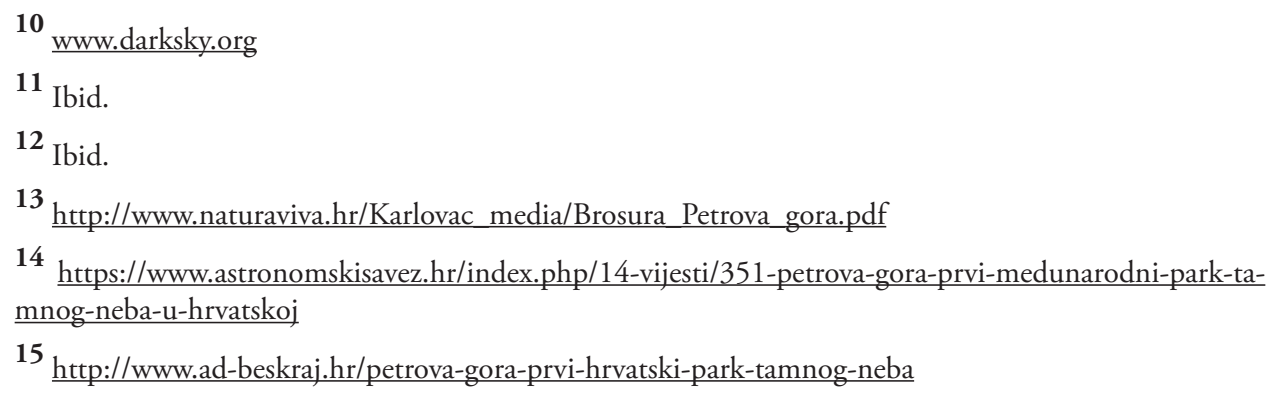


no atraktivnom destinacijom za astronomske i druge znanstvene aktivnosti. Međutim, u IDA-i ističu da se takve aktivnosti na Petrovoj gori provode još od 2007. godine, što je čini, kako navode, ,jednom od najpopularnijih hrvatskih destinacija za promatranje zvijezda i astrofotografiju“. ${ }^{16}$

Zanimljivo je naglasiti da certificirano područje Petrova gora - Biljeg pripada dvjema županijama, koje zajednički upravljaju tim zaštićenim područjem. To čine Javna ustanova Natura Viva za Karlovačku županiju i Javna ustanova za upravljanje zaštićenim prirodnim područjima Sisačko-moslavačke županije. Dijelom područja pokrivenim šumama upravljaju Hrvatske šume. Inicijator procesa aplikacije za dobivanje certifikata je Astronomsko društvo Beskraj iz Zagreba. Uvjet za dobivanje certifikata, kako dalje navode u IDA-i, bio je da sve četiri spomenute institucije zajednički surađuju na zaštiti područja od svjetlosnog onečišćenja.

Petrova gora se dobivanjem certifikata priključila 15 drugih lokacija s IDSP certifikatom u Europi, što će pospješiti napore protiv svjetlosnog onečišćenja u Hrvatskoj i šire. Ističu i da se certifikat „nadovezao na hrvatske napore u kontroli svjetlosnog onečišćenja, budući da je nešto prije toga Hrvatska donijela jedne od najnaprednijih zakona u kontroli svjetlosnog onečišćenja“. Prema tom zakonu, kako navode, sva zaštićena područja u Hrvatskoj moraju imati potpuno zaštićena rasvjetna tijela s maksimumom CCT-a od $2200 \mathrm{~K}$ te su zabranjena osvjetljenja jumbo plakata. ${ }^{17}$

S obzirom na to da je ujedno riječ o zaštićenom području prirode, taj certifikat u velikoj mjeri pospješuje daljnji razvoj održivog turizma u tom području, što je i navedeno u brošuri Javne ustanove Natura viva kao jedan od strateških ciljeva razvoja područja.

Evo kako su neki od medija popratili međunarodno certificiranje Zaštićenog područja prirode Petrova gora - Biljeg u kategoriji Međunarodnog parka tamnog neba:

Oznaka medunarodnog parka tamnog neba jedinstven je način promocije zaštite noćnog neba na svijetu, a time ujedno i posebno priznanje zaštićenom krajobrazu kojim se dobiva dodatna vrijednost $i$ atraktivnost ne samo u smislu zaštite prirode, već $i$ u turističkoj ponudi. ${ }^{18}$

Procjenjuje se da više od $80 \%$ stanovništva Europe više ne može vidjeti Mliječni put iz svog mjesta boravišta. Hrvatska je jedna od država s najvećim rastom svjetlosnog onečišćenja u Europi, a godišnja potrošnja električne energije za javnu rasvjetu po stanovniku dvostruko

\footnotetext{
16 https://www.darksky.org/croatia-earns-first-international-dark-sky-place-at-petrova-gora-biljeg

17 https://www.darksky.org/croatia-earns-first-international-dark-sky-place-at-petrova-gora-biljeg/

18 https://www.h-alter.org/vijesti/proglasen-prvi-medjunarodni-park-tamnog-neba-u-hrvatskoj, M.K. 20.06.2019.
} 
veća je nego, recimo, u susjednoj Sloveniji. Svjetlosno onečišćenje gradova prostire se više od stotinu kilometara u okolišs, čime nanosi ogromnu štetu ekosustavu na velikim udaljenostima. Ipak, u Hrvatskoj još uvijek postoje lokacije s vrlo tamnim noćnim nebom, što je važno ne samo radi očuvanja bioraznolikosti, već i razvoja astroturizma kao jedinstvene turističke ponude tijekom cijele sezone. Proglašenje međunarodnog parka tamnog neba ima veliki značaj za promociju Hrvatske kao destinacije u kojoj se njeguje važnost očuvanja tamnog noćnog neba kao prirodnog ritma izmjene dana $i$ noći. ${ }^{19}$

Posebno je zanimljivo istaknuti navode iz Astronomskog društva Beskraj povodom dobivanja certifikata, a koje također prenosi www.hrturizam.hr. U njima se očituju o zabrinutosti u vezi svjetlosnog onečišćenja u Hrvatskoj.

Mjerenja svjetlosnog onečisćenja na Petrovoj gori pokazuju da je čak i ovdje nebo 1,5 puta svjetlije od prirodnog noćnog neba, pa će kroz suradnju s obližnjim općinama $i$ implementaciju novog Zakona o zaštiti od svjetlosnog onečisćenja biti potrebno puno truda da se spriječi povećanje svjetlosnog onečišćenja na području Parka [...] Od Petrove gore u Hrvatskoj ima i tamnijih lokacija kao što su Lastovo, Lika $i$ Velebit, te neki otoci poput Cresa, Visa, Mljeta i Kornata, no nisu lako dostupne kao Petrova gora. Nažalost, razvitak ljetnog turizma na hrvatskoj obali u potpunosti ignorira turistički potencijal romantičnih šetnji uz more stamnim nebom prepunim zvijezda i pogledom na Mliječni put, u korist zasljepljujuće i nepotrebne LED rasvjete te bliještećih reklama [...] Nadamo se da će proglašenje parka tamnog neba osvijestiti važnost očuvanja tamnog neba ne samo kao turističkog potencijala, već i zbog zaštite ljudskog zdravlja i cijelog ekosustava koji je tijekom stotina milijuna godina evoluirao uz prirodnu izmjenu dana $i$ noći. ${ }^{20}$

Dana 20. studenog 2019. godine Astronomski savez Hrvatske informirao je javnost o još jednom proglašenju Međunarodnog parka tamnog neba, priopćenjem pod nazivom „Hrvatska dobila još jedan park tamnog neba!“ Slijedi njihovo priopćenje:

Danas je održana Tiskovna konferencija povodom proglašenja Mecunarodnog parka tamnog neba „Vrani kamen“. Velika nam je čast i zadovoljstvo objaviti da je Park „Vrani kamen" postao drugi hrvatski Medunarodni park tamnog neba, po strogim kriterijima Mecunarodne organizacije za zaštitu tamnog neba (International Dark-Sky Association - IDA), američke neprofitne organizacije, jedine takve na globalnoj razini, čija je zadaća očuvati i zaštititi noćni okoliš i baštinu noćnog neba putem kvalitetnih osvjetljenja eksterijera, s ciljem očuvanja prirodnog blaga i velikog potencijala nezagadenog noćnog krajolika i gotovo netaknute prirode.

\footnotetext{
19 https://hrturizam.hr/petrova-gora-prvi-medunarodni-park-tamnog-neba-u-hrvatskoj/ 20 Ibid.
} 
Međunarodni park tamnog neba Vrani kamen nalazi se u neposrednoj blizini grada Daruvara i proteže se na površini od 8000 hektara zapadnog dijela planine Papuk. Većim dijelom njime upravljaju Hrvatske šume, dok je područje Petrovog vrha pod upravom Grada Daruvara. Prema navodima Hrvatskog astronomskog saveza riječ je o lokalitetu koji astronomi već dugi niz godina koriste za opservacije Svemira, a godinama ujedno rade i na podizanju svijesti o problematici svjetlosnog zagađenja i zaštiti noćnog krajolika.

Važno je spomenuti i projekt Grada Daruvara „Ugasiti svjetla, a upaliti zvijezde“, koji ima za cilj zastarjelu javnu rasvjetu na području Grada zamijeniti novom koja odgovara svim ekološkim standardima.

Međunarodni park tamnog neba Vrani kamen i grad Daruvar sa svojim prirodnim i kulturnim znamenitostima i bogatstvima pogodni su za razvoj astroturizma, kao i znanstvenoga turizma. Grad ujedno razvija i druge selektivne oblike turizma kao što su: zdravstveni turizam, gastronomski turizam, ruralni turizam i dr.

\subsection{Aktivnost i certifikati IAC-a}

Institut astrofizike Kanarskih otoka (Institute of Astrophysics of the Canary Islands IAC) španjolska je javna istraživačka institucija osnovana 1982. godine. Jedni su od inicijatora donošenja Međunarodne deklaracije o zaštiti noćnog neba i prava na svjetlost zvijezda - La Palma ili Starlight deklaracije, opisane ranije u ovom radu. Smatra se da oni postavljaju standarde kada je u pitanju astrofizika, napredni znanstveni instrumentarij, sveučilišna edukacija i popularizacija znanosti, posebice astronomije. Opservatoriji IAC-a na Tenerifama (Teide Observatory) i La Palmi (Roque de los Muchachos Observatory), tzv. Sjeverni europski opservatoriji - European Northern Observatory (ENO), instalirali su teleskope i instrumente kojima opslužuju čak preko 60 znanstvenih institucija iz 90 zemalja svijeta. Opservatorij The Roque de los Muchachos posjeduje najveći i najnapredniji optički infracrveni teleskop na svijetu - Gran Telescopio Canarias, koji je dizajniran i izgrađen u IAC-u.

Nakon donošenja Deklaracije iz La Palme pokrenuta je inicijativa Starlight kao međunarodni pokret u obrani noćnog neba i prava na svjetlost zvijezda, u skladu s principima i ciljevima Deklaracije. Pri tome u IAC-u ističu tri ključna strateška cilja - dimenzije:

1. Znanstvena dimenzija - valorizirati i sačuvati kvalitetu zvjezdanog neba kao conditio sine qua non za astrofizičke opservacije pomoću teleskopa u nastojanju da se na taj način slijede najbolji i najviši standardi znanstvenog istraživanja.

2. Kulturna dimenzija - širiti javni interes o astronomiji te usmjeravati pažnju javnosti na vrijednost noćnog neba, ne samo u cilju provođenja astrofizičkih istraživanja već i zbog očuvanja znanstvene, kulturne i okolišne baštine za buduće generacije. 
3. Ekonomska dimenzija - jačati ekonomiju kroz mogućnosti za „kontemplaciju i interpretaciju zvjezdanog neba“, izgradnju infrastrukture za tu svrhu te promociju proizvoda i aktivnosti na području održivog turizma, koje nazivamo „zvjezdani turizam" (engl. star tourism). ${ }^{21}$

Zahvaljujući naporima IAC-a došlo je do donošenja „pionirskog“ zakona po pitanju zaštite noćnog neba na otocima La Palma i Tenerife. Riječ je o aktu Act 31/198822, koji je postao preteča za donošenje kasnijih sličnih zakona u drugim dijelovima svijeta, pa tako i u Hrvatskoj.

$\mathrm{Na}$ svojoj internetskoj stranici znanstvenici i stručnjaci organizacije IAC navode da noćno nebo smatraju „iznimnom, univerzalnom kulturnom vrijednošću i vitalnim uvjetom za promociju i razvoj 'astronomskog turizma', a ne samo kao nužan uvjet za znanstvena istraživanja kojima promatraju i proučavaju Svemir. “23

Na temeljima Prve međunarodne konferencije o zvjezdanom nebu (First International Starlight Conference) 2009. godine osnovana je Starlight fondacija (Fundación Starli$g h t)$. Glavni cilj Fondacije popularizacija je astronomije i diseminacija istraživanja na području astronomije, kao i koordinacija, menadžment i promocija principa i filozofije tzv. Starlight pokreta po cijelom svijetu. Riječ je o neprofitnoj organizaciji čiji je primarni cilj razvijati programe i aktivnosti u cilju zaštite zvjezdanog neba. ${ }^{24}$ Zanimljivo je napomenuti da je u travnju 2017. godine održano prigodno obilježavanje desete godišnjice donošenja Deklaracije iz La Palme, gdje su potvrđena i revidirana njena načela te su joj se pridružile još neke organizacije.

Važno je istaknuti da se astroturizam i njegov razvoj implementirani u svim četirima ciljevima Starlight fondacije:

1. Zaštita noćnog neba, pri čemu se navodi da je noćno nebo važan „znanstveni, kulturni, okolišni i turistički resurs." ${ }^{25}$

2. Kulturna diseminacija istraživanja o astronomiji na inovativne načine, pri čemu se, kako navode na internetskoj stranici IAC-a, astronomija treba povezivati s društvom „kroz turističke aktivnosti povezane uz zvijezde, izgrađujući mrežu tzv. Starlight ruralnih kuća za odmor i Starlight hotela, promovirajući Stellariume tamo gdje se mogu organizirati festivali i druge aktivnosti na temu astronomije, kreirajući kontekst za astrofotografiju i drugo“. Cilj je, kako navode, „disemina-

\footnotetext{
21 www.iac.es

22 https://www.fundacionstarlight.org/en/section/history/281.html 23 www.iac.es

${ }^{24}$ https://www.fundacionstarlight.org/en/section/history/281.htm 25 Ibid.
} 
cija znanosti na zabavan način, kreirajući prostore za rekreaciju, primjerice, na lokacijama koje su dobile ili su u procesu dobivanja certifikata Starlight turističke destinacije (Starligth Tourist Destination)“. U IAC-u pritom naglašavaju da je u tom smislu vrlo važno organizirati specijalne treninge i programe edukacije koje će specijalizirani stručnjaci i vodiči, tzv. Astronomical Monitors and Starlight Guides, održavati za širu populaciju.

3. „Zvjezdani“ turizam. Riječ je o promociji specifičnog oblika znanstvenog turizma koji se pod nazivom Star Tourism razvija kao rastući, održiv oblik turizma visoke kvalitete. U tu svrhu Fondacija je razvila certifikacijski sustav kroz koji se certifikat Starlight turističke destinacije - Starligth Tourist Destination - dodjeljuje onim mjestima u kojima kvaliteta neba i infrastrukture dopušta razvoj aktivnosti zvjezdanog turizma. Osim tog certifikata, Fondacija dodjeljuje i status Starlight rezervata (Starlight Reserve) onim područjima koja održavaju, čuvaju prirodno osvjetljenje i jasno noćno nebo, a koja ujedno inkorporiraju promatranje zvjezdanog neba u postojeću prirodnu i kulturnu baštinu. Starlight rezervati sastoje se od središnje (engl. core, exlusion) zone, zone zaštite i opće zone. Središnja zona je područje u kojemu su uvjeti prirodnog svjetla i jasnoća noćnog neba ostali netaknuti. Zona zaštite (engl. protection zone) locirana je pored središnjeg područja i služi za obranu od negativnih učinaka svjetlosnog onečišćenja. Opća zona okružuje navedene zone i nalazi se izvan područja rezervata, a u njoj je potrebno primijeniti kriterije pametne i odgovorne rasvjete. Cilj je da se u takvim rezervatima sačuvaju uvjeti za astronomska promatranja, zaštitu prirodne i kulturne baštine i njihovu integraciju u noćni krajolik zvjezdanog neba. Certifikaciju prati Participacijski akcijski plan, koji se sastoji od strogih preporuka koje imaju za cilj „zaštitu ili obnovu kvalitete noćnog neba, uzevši u obzir kulturne, edukacijske, znanstvene i okolišne koristi. “26

4. Pametna rasvjeta i ušteda energije - Fondacija se također bori za izgradnju „kulture racionalne rasvjete " koja omogućuje štednju energije, razvoj zvjezdanog turizma u različitim dijelovima svijeta i zaštitu biljnih i životinjskih vrsta koje traže nezagađeno noćno nebo kao uvjet svog opstanka. ${ }^{27}$

$\mathrm{Na}$ internetskoj stranici IAC-a navode kako je razvoj astroturizma „u područjima koja se brinu o noćnom nebu“ jedan od glavnih ciljeva Fondacije.

U okviru certifikacije ugostiteljskih objekata u astroturizmu, Starlight certifikacija obuhvaća kategorije ruralnih hotela i kuća. Te certifikate dobivaju oni ugostiteljski objekti koji su, pored kvalitetne smještajne ponude, aktivno uključeni u promociju vrijednosti Deklaracije iz La Palme i koji opskrbljuju svoje goste informacijama o Starlight projektu te raspolažu opremom i instrumentima za astronomsku opservaciju.

\footnotetext{
26 Ibid.

27 Ibid.
} 
Certifikacija također obuhvaća kategoriju Starlight Zvjezdanih parkova (Starlight Stellar Parks), koji se definiraju kao ruralna područja koja ne moraju nužno biti velika površinom, a odnose se na područja - lokalne zajednice koje „čuvaju noćno nebo u dovoljnoj mjeri“ da su time stečeni uvjeti za realizaciju aktivnosti astronomske opservacije te kulturne i rekreacijske aktivnosti vezane uz astronomske događaje, kao što su, primjerice, prolazi kometa, pomrčine Sunca i Mjeseca, promatranje položaja planeta, meteorske kiše i slično. Oni raspolažu instrumentarijem za astronomske opservacije, a namijenjeni su uglavnom astronomima amaterima. Kako se takva područja nalaze u blizini urbanih zona, nužno ih je zaštititi od svjetlosnog zagađenja, uzevši u obzir topografiju njihove lokacije. U tom smislu treba postojati zalaganje javnih i privatnih entiteta za implementacijom pametne i održive rasvjete u privatnim i javnim prostorima. $^{28}$

\subsection{Projekt Astronomski ekoturizam i Astronomitaly}

Projekt naziva Astronomski ekoturizam (Ecoturismo Astronomico), preciznije Mreža astronomskog ekoturizma (Rete del Turismo Astronomico), nastao je u Italiji s ciljem promocije ekološkog astroturizma u zemlji. Kreirala ga je skupina pasioniranih astronoma sa željom, kako navode, ,za valorizacijom izvrsnosti 'teritorija iznad nas' te njegove povezanosti s tradicijom, pričama i ljepotom Zemlje“. ${ }^{29}$ Projekt je 2014. godine nagrađen Nagradom za talijanske talente (Premio Talento Italiano), koju dodjeljuje više talijanskih institucija, među kojima je, primjerice, Talijansko udruženje za odgovorni turizam (Associazione Italiana Turismo Responsabile - AITR). Ta se nagrada dodjeljuje aktivnostima koje podržavaju razvoj „mekog turizma“30, koji ne oštećuje okoliš već valorizira njegove specifičnosti i ljepote. ${ }^{31}$

Cilj tog projekta razvoj je, kako ga nazivaju, astronomskog turizma u Italiji, kao „novog oblika odgovornog i održivog turizma, koji poštuje prirodu i čuva nebo kao baštinu“. Riječ je o prvom projektu takvog tipa u Italiji. Pod geslom „Otkrij najbolja mjesta i iskustva za promatranje zvijezda“ unutar tog projekta realizira se i certifikacija u astroturizmu (International Astrotourism Certification), koja ima za cilj promovirati, kako navode, „neka od najboljih mjesta na svijetu za promatranje zvijezda i spavanje pod zvjezdanim nebom“. Certifikate dobivaju turističke destinacije / jedinice lokalne samouprave koje su sačuvale ljepote zvjezdanog neba i nude kvalitetne ugostiteljske usluge te u kojima postoje opservatoriji i planetariji, hoteli i drugi smještajni objekti te

\footnotetext{
28 Ibid.

29 www.astrotourism.com

30 Tal. turismo dolce, u doslovnom prijevodu: „slatkog turizma“

31 Ibid.
} 
zaštićeni prirodni lokaliteti. U sklopu certifikacije u tom projektu dodjeljuju se nagrade „za najljepše nebo Italije“ u kategorijama: zlato, srebro i bronca. U sklopu projekta promoviraju se turistički proizvodi u skupinama - Iskustva, Eventi i Putovanja. Za dio certifikacije i turističke promocije proizvoda u astroturizmu zadužen je program Astronomitaly unutar cjelokupnog projekta, koji ima za cilj razvoj astroturizma kao održivog turizma visoke kvalitete. ${ }^{32}$

Može se zaključiti da sva tri prikazana projekta obilježava sljedeće:

- Snažno zalaganje za razvoj astroturizma kao novog selektivnog oblika turizma koji se nadovezuje na druge oblike turizma i konvergira s njima.

- Kao najvažniji preduvjet razvoja astroturizma postavlja se svjetlosno nezagađeno nebo. Zaštita od svjetlosnog onečišćenja implementira se na široj platformi i uključuje brojne relevantne dionike iz javnog i privatnog sektora.

- Svjetlosno onečišćeno nebo smatra se baštinom i neotuđivim pravom čovječanstva.

- Astroturizam ispunjava brojne funkcije: društvenu, gospodarsku, ekološku, razvojnu, edukativnu, zabavnu i druge. U ekološkom smislu, astroturizam je jedan od glavnih čimbenika zaštite protiv svjetlosnog onečišćenja.

- U cilju bolje promocije astroturizma i zaštite od svjetlosnog onečišćenja provodi se certifikacija u astroturizmu, kako na globalnoj (IDA, IAC) tako i na nacionalnoj razini (Astronomitaly). Time se u sustav astroturizma implementiraju koncept i principi upravljanja kvalitetom. Certificiraju se određeni lokaliteti - prirodni lokaliteti, urbane zone, turističke destinacije i turistički objekti koji zadovoljavaju propisane kriterije. Time epitet astroturističke destinacije dobiva svoju ne samo tržišnu već i javno-društvenu artikulaciju, jer je jedan od najvažnijih ciljeva certificiranja edukacija i senzibilizacija javnosti za problematiku svjetlosnog onečišćenja te popularizacija astronomije. Može se stoga reći da certifikacija u astroturizmu značajno nadilazi marketinške (komercijalne) i gospodarske ciljeve te ujedno ispunjava i značajnu javno-društvenu i ekološku funkciju.

- U IDA-i ističu da se procjenjuje da „veći dio europske populacije više ne može vidjeti Mliječnu stazu“ (IDA). To, međutim, nije slučaj za cjelokupno područje Republike Hrvatske, na kojemu postoji još značajan potencijal za razvoj astroturizma, a do sada su certifikat dobila dva Parka tamnog neba: Petrova gora - Biljeg i Vrani kamen. Stoga u Republici Hrvatskoj postoje značajni potencijali za razvitak astroturizma. 


\section{Rezultati istraživanja $i$ rasprava}

Metodom deskriptivne analize triju međunarodnih projekata koji imaju za cilj razvoj astroturizma došlo se do određenih odgovora na postavljene hipoteze i istraživačka pitanja. Analizirana su tri međunarodna projekta: IDA, sa sjedištem u SAD-u, IAC, sa sjedištem na španjolskim Kanarskim otocima te projekt Astronomski ekoturizam (Ecoturismo Astronomico), sa sjedištem u Italiji, od kojih prva dva djeluju na međunarodnoj, a treći na nacionalnoj razini. Svi promatrani projekti orijentirani su na ekološku dimenziju očuvanja i zaštite noćnog neba od svjetlosnog onečišćenja, prvenstveno kroz razvoj astroturizma. Riječ je, naime, o važnom globalnom održivom cilju - zaštiti neba od svjetlosnog (i drugih oblika) zagađenja, koja je svoju prvu ,javnu artikulaciju“ dobila donošenjem Deklaracije iz La Palme 2007. godine, kojom se zaštita noćnog zvjezdanog neba proglašava pravom čovječanstva.

U tom kontekstu pojavljuje se astroturizam kao jedan od selektivnih oblika turizma u funkciji ostvarenja tog važnog globalnog cilja, što daje naslutiti da se razvijaju i podupiru takve forme turizma („nježni“ ili „meki turizam“), koje ne iscrpljuju i ne zagađuju prostor, već ga preoblikuju (redimenzioniraju) i valoriziraju na održiv i odgovoran način. $U$ radu je pokazano da su kako strateški dokumenti na međunarodnoj razini tako i pojedinačni projekti i lokalne strategije u promatranim projektima kao jedan od ključnih ciljeva, a ujedno i najvažniji preduvjet za razvoj astroturizma, postavili svjetlosno nezagađeno nebo. Time se potvrđuje prva hipoteza postavljena u ovom radu. Pored navedenog, u projektima se navode educirani stručnjaci (astrovodiči) te oprema i instrumentarij za astronomske opservacije.

Kako bi se očuvala i valorizirala vrijednost i kvaliteta pojedinih lokaliteta, turističkih destinacija i ugostiteljskih objekata u astroturizmu, ali i diferencirala od ostalih, svi su analizirani projekti u svoje aktivnosti uključili certificiranje područja, lokacija i objekata u astroturizmu. Uočeno je, međutim, da se IDA fokusirala na certificiranje prirodnih područja i turističkih destinacija, dok se kroz druga dva promatrana projekta certifikati dodjeljuju i ugostiteljskim objektima u ruralnom prostoru koji nude uvjete i opremu za astroturističke aktivnosti. Time je ujedno dokazana i druga hipoteza postavljena u ovom radu, a to je da je certifikacija u astroturizmu iznimno bitna za njegov razvoj, a da certifikati u astroturizmu imaju nekoliko dimenzija i aspekata: upravljanje kvalitetom, marketinški, a time ujedno i komunikacijsko-informativni aspekt, edukativni aspekt, ekološko-pravni aspekt (promoviranje pravne regulative o zaštiti od svjetlosnog onečišćenja) i slično. Svakako ovdje treba naglasiti i hrvatske uspjehe: Hrvatska je nedavno dobila dva certifikata o zaštiti tamnog neba - dva certifikata u kategoriji Park tamnog neba, i, što je vrlo važno, obje se te lokacije nalaze na kontinentu, a ujedno i u zaštićenim prirodnim područjima, što je od velikog značenja za daljnji razvoj održivog turizma u Hrvatskoj, posebice u njenom kontinentalnom dijelu. 
Zaključne teze ovoga rada mogu se ukratko sažeti ovako:

1. Nakon donošenja Deklaracije iz La Palme 2007. godine može se reći da je astroturizam dobio svoju međunarodnu afirmaciju, istovremeno s proglašenjem prava čovječanstva na mračno (svjetlosno nezagađeno) zvjezdano nebo.

2. Osim navedenog, najvažnijeg uvjeta, unutar analiziranih projekata eksplicitno se ili implicitno navode i drugi preduvjeti za njegov razvoj, a to su:

- odgovarajući stručni kadar - astrovodiči, astronomi - amateri i profesionalci

- infrastrukturni uvjeti - odgovorna i održiva javna rasvjeta i održivo vanjsko umjetno osvjetljenje privatnih prostora te oprema i instrumentarij za astronomske opservacije, a navode se čak i uvjeti za astrofotografiju

- $\quad$ stakeholderski princip - uvjet suradnje - u svim trima analiziranim projektima zauzet je jasan stav da se zaštita noćnog neba i astroturizam mogu realizirati isključivo općim konsenzusom i kontinuiranom suradnjom svih ključnih dionika, kako u javnom, tako i u privatnom sektoru, na temelju čega se može zaključiti da je astroturizam i njegov razvoj zapravo svojevrsni projekt javnoprivatnog partnerstva

- $\quad$ strateški - jasno je da zaštita noćnog neba i razvoj astroturizma trebaju biti uključeni u razvojne strategije na svim razinama - od globalne, preko nacionalne do lokalne

- financijski - što se financija tiče, zanimljivo je napomenuti da se na internetskoj stranicama navedenih projekata kao ni u samoj Deklaraciji iz La Palme izričito ne spominje financiranje, no može se zaključiti da se sredstva financiranja mogu iznaći iz sredstava EU fondova, iz javnih sredstava te iz privatnih marketinških proračuna.

3. Kada je riječ o znanstvenom aspektu istraživanja, autori jednoglasno navode da još uvijek ne postoji konceptualni jasno definiran okvir istraživanja, kao ni jasna ni jednoznačna definicija astroturizma, astroturističke destinacije, turističkih aktivnosti u astroturizmu i slično. Međutim, u posljednjih dvadesetak godina brojni znanstvenici širom svijeta nastoje iznaći odgovore i definirati ovaj rastući oblik održivog turizma, koji se ubrzano razvija po cijelom svijetu. Rad ujedno ima za svrhu bolje razumijevanje pojma i koncepta astroturizma, s posebnim osvrtom na certifikaciju na tom području.

4. Kao praktične implikacije ovoga rada prije svega treba istaknuti poticaj za razvoj astroturizma i na području Hrvatske, koja za to ima brojne pogodnosti budući da su neki geografski dijelovi Hrvatske još uvijek svjetlosno očuvani (slika 3). Proglašenje dvaju lokaliteta Međunarodnim parkovima tamnoga neba, kao i zakonska regulativa na području zaštite od svjetlosnog onečišćenja u Hrvatskoj pokazuju da je Hrvatska na dobrom putu, no ipak su to tek inicijalni koraci. Stoga bi razvoj astroturizma i zaštitu od svjetlosnog onečišćenja u odgovarajuća geografska područja trebalo implementirati u ključne razvojne dokumente, kako one općeg tako i one turističkog razvoja. U tom smislu, certifikacija se u astroturizmu treba nastaviti, a bilo bi uputno formirati i središnje tijelo za razvoj astroturizma u $\mathrm{Hr}$ - 
vatskoj, po uzoru na opisane projekte u Španjolskoj i Italiji. Financiranje takvog razvoja moglo bi biti mješovito: sredstva EU fondova, javna i privatna sredstva, fondacije, sponzorstva i slično.

5. I konačno, zanimljivo je identificirati sinergijski potencijal astroturizma - osim što se njegovim razvojem ispunjavaju ekološki, društveni, gospodarski, edukativni i znanstveni ciljevi, istovremeno se kroz njegov razvoj pospješuje i ostvarenje drugih ciljeva kao što su: lokalni razvoj, razvoj ruralnih područja, prirodna zaštita, promocija kulturne baštine i slično. Također se uočava i marketinški razvoj proizvoda u astroturizmu, kao što su kreiranje i promocija diferenciranih proizvoda u kategoriji astroturizma, a to su: putovanja, iskustva, događanja i slično, koje se već $\mathrm{u}$ respektabilnoj mjeri razvilo, posebice promocijom kroz digitalne kanale.

Kao smjernice za daljnja istraživanja mogu se preporučiti daljnje analize, međunarodne komparacije i studije slučaja, kojima će se pokušati definirati precizniji konceptualni okvir, ali i poslovni model razvoja astroturizma, te multidisciplinarna istraživanja kojima će se istražiti bolji načini senzibiliziranja javnosti za problem svjetlosnog onečišćenja, ali i novi modeli razvoja astroturizma i optimizacije njegovih društvenih, ekoloških i gospodarskih učinaka, prvenstveno u cilju razvoja održivog turizma i zaštite prirode i mračnog neba.

\section{Zaključak}

U ovom aktualnom trenutku preispituje se značenje i uloga turizma, kao jedne od osnovnih društvenih i gospodarskih pojava današnjice. Ovaj oblik turizma, koji nas vraća u mitsko, iskonsko iskustvo „gledanja zvijezda“, razvija se u sklopu međunarodnih projekata koji imaju za cilj očuvanje i zaštitu tamnoga neba, odnosno senzibiliziranje javnosti i zaštitu od svjetlosnog onečišćenja, koja je započela donošenjem tzv. Starlight deklaracije 2007. godine. Riječ je o inovativnom obliku turizma koji se zasniva na imaginaciji, introspekciji i težnji za odgovorima o smislu postojanja, beskonačnosti Svemira i introspekciji. Radom se daje prikaz konceptualnog okvira astroturizma s posebnim osvrtom na uvjete i certifikate za njegov razvoj, uz deskriptivnu komparativnu analizu triju međunarodnih projekata. Temeljem analize prikazanih projekata uočeno je da je astroturizam postao važan čimbenik popularizacije i senzibilizacije znanosti, stručnjaka i javnosti u pogledu zaštite noćnog neba od svjetlosnog onečišćenja.

U radu se zaključuje da je astroturizam jedan od međunarodno priznatih, održivih i odgovornih oblika turizma koji je u porastu i koji, osim ekonomske, ujedno zadovoljava i druge funkcije kao što su: edukacijska, znanstvena, ekološka, razvojna i druge. Može se reći da se u tom smislu ne radi tek o jednom novom obliku selektivnog turizma, već i više od toga - riječ je o novom trendu i razvojnome pravcu kojim turizam (ali i cijelo gospodarstvo) treba krenuti - ne protiv, već u suglasnosti s prirodom. 
Prikazane analize u ovom radu, kao i brojne druge studije slučaja u znanstvenoj literaturi, ukazuju na razvojni pravac turizma budućnosti. Znanost i praksa jednoglasni su u stavu da je masovni turizam jednostavno „prevršio svaku mjeru“, a da treba ići u smjeru novih, mekih, „nježnih“ oblika turizma, koji prirodu i prirodne procese neće narušiti, već će ih, naprotiv, redimenzionirati i revalorizirati. Astroturizam, kao oblik turizma gdje se vraćamo iskonskome, introspekciji, mašti, ali i edukaciji, novim saznanjima pa i romantici, zasigurno slijedi i sociološke trendove o „novoj duhovnosti“ čovjeka, o novim promišljanjima i novim prostorima. To i je parafraza slogana „meditiramo uz zvijezde mi koji smo sačinjeni od zvijezda“, kojim se potvrđuje naša iskonska potreba za odgovorima i višim smislom. Stoga, ma koliko astroturizam bio nov fenomen u svom suvremenom obliku, moglo bi se reći da se preteča astroturističke aktivnosti dogodila onda kada je prvi put čovjek pogledao u noćno nebo. Ili kada su drevni astronomi/proroci predviđali zbivanja na osnovi kretanja i položaja planeta. Ili kada su biblijska tri mudraca „slijedila zvijezdu da pronađu novorođenog Kralja“... Bilo koji od tih aspekata (svog vlastitog) pogleda u zvijezde da je čovjek osjetio, neosporna je činjenica da su ljudi oduvijek fascinirani pogledom u nebo i nebeska tijela. Zato je astroturizam, kao „turizam zagledan u zvijezde“, neosporno ne samo jedan od oblika turizma koji će se vrlo vjerojatno sve više razvijati u budućnosti već može služiti i kao „ogledni primjer“ kakav turizam treba razvijati u „vrlom novom svijetu“, ili, kako ga češće stručnjaci i mediji nazivaju - „u novoj normalnosti“. A to je turizam koji je podjednako okrenut čovjeku i prirodi i koji ih (opet) približava na nove načine.

\section{Literatura}

1. Andreić, Ž.; Korlević, K.; Andreić, D.; Bonaca, A.; Korlević, P; Kramar, M. (2011). Svjetlosno onečišćenje u Republici Hrvatskoj. Gradevinar, 63 (8): 757 764.

2. Austin, M. E.; Hearnshaw, J. B.; Butler, S.; Loveridge, A. (2012). An Application to the International Dark-Sky Association for a Starlight Reserve in the Aoraki/Mt Cook National Park and the Mackenzie Basin of the central South Island of New Zealand, xii + 167. http://www.saps.canterbury.ac.nz/starlight/

3. Belij, M. and Tadić, M. (2015). Astrotourism - possibilities for development in Serbia. Glasnik Srpskog geografskog društva, 95 (3): 59-73. https://doi. org/10.2298/GSGD1503059B

4. Caballero-Sánchez, E.; Sánchez-Medina, A. J.; Alonso-Hernández, J. B.; VoltesDorta, A. (2019). Astrotourism and night sky brightness forecast: first probabilistic model approach. Sensors, 19 (13), 2840.: 1-16. https://doi.org/10.3390/ $\underline{\text { s19132840 }}$

5. Cater, C. I. (2010). Steps to Space; opportunities for astrotourism. Tourism Management, 31 (6): 838-845. https://doi.org/10.1016/j.tourman.2009.09.001

6. Cater, C. (2019). History of Space Tourism. Space Tourism. Tourism Social Science Series, 25: 51-66. Emerald Publishing Limited. https://doi.org/10.1108/S1571$\underline{504320190000025003}$ 
7. Cinzano, P.; Falchi, F; Elvidge, C. D. (2001). The First World Atlas of the Artificial Night Sky Brightness. Monthly Notices of the Royal Astronomical Society, 328 (3): 689-707. https://doi.org/10.1046/j.1365-8711.2001.04882.x

8. Collison, F. M. and Poe, K. (2013). „Astronomical Tourism”: The Astronomy and Dark-Sky Program at Bryce Canyon National Park. Tourism Management Perspectives, 7: 1-15. https://doi.org/10.1016/j.tmp.2013.01.002

9. Fayos-Solá, E.; Marín, C. and Jafari, J. (2014.). Astrotourism: No requiem for meaningful travel. Pasos. Revista de Turismo y Patrimonio Cultural, 12 (4): 663671. https://doi.org/10.25145/j.pasos.2014.12.048

10. Hearnshaw, J. (2015). The Aoraki Mackenzie international Dark-Sky reserve and light pollution issues in New Zealand. IAU General Assembly, 22. https:// ui.adsabs.harvard.edu/abs/2015IAUGA..2226774H/abstract

11. Herrero, I. A. H. (2019). Unified definition of the term astrotourism (Bachelor Degree Tesis). Universitat de Barcelona. https://tinyurl.com/y4a55xp7

12. Holbrook, J.; Medupe, R. T. and Urama, J. O. (Eds.). (2008). African Cultural Astronomy - Current Archaeoastronomy and Ethnoastronomy research in Africa. Springer. https://www.springer.com/gp/book/9781402066382

13. Honorato, V. B. i Violin, F. L. (2020). Astroturismo: uma análise no Parque Estadual Morro do Diabo, Teodoro Sampaio, São Paulo. Turismo e Sociedade, 12 (3): 1-15. http://dx.doi.org/10.5380/tes.v12i3.69785

14. Ingle, M. (2010). Making the most of 'nothing': astro-tourism, the Sublime, and the Karoo as a 'space destination'. u: Transformation: Critical Perspectives on Southern Africa. 74: 87-111. https://doi.org/10.1353/trn.2010.0013

15. Jacobs, L.; Du Preez, E. A. and Fairer-Wessels, F. (2020). To wish upon a star: Exploring Astro Tourism as vehicle for sustainable rural development. Development Southern Africa, 37 (1): 87-104. https://doi.org/10.1080/037683 5X.2019.1609908

16. Jiwaji, N. T. (2016). Astro-Tourism as a High Potential Alternative Tourist Attraction in Tanzania. Huria: Journal of the Open University of Tanzania, 23 (1): 106-113. https://www.ajol.info/index.php/huria/article/view/152728

17. Korlević, K. i Krajnović, A. (1999). Razvoj astroturizma u Višnjanu. Tourism and Hospitality Management, 5 (1-2): 85-96. https://hrcak.srce.hr/181928

18. Kulvinder, D.; Bichang'a, B.; Wafula, M.; Meli, E.; Osoro, B.; Ndritu, S.; Akumu, P.; Orieko, A.; Mutisya, K.; Kiyanjui, C.; Manikumar, S.; Baki, P. (2020). Astrotourism in The Mara. African Journals Online (AJOL), 23 (1). https:// www.capjournal.org/issues/27/27_20.pdf

19. Kunjaya, C.; Sukmaraga, A. A and Arsono, T. (2019). Possibility of astronomical phenomena to be used to support tourism industry. Journal of Physics: Conference Series, 1231 (1), 012025. IOP Publishing. https://iopscience.iop.org/ article/10.1088/1742-6596/1231/1/012025/meta

20. Matos, A. L. (2017). Terrestrial Astrotourism - Motivation and Satisfaction of Travelling to Watch the Night Sky (Master's Thesis). Aalborg University. https:// tinyurl.com/y6agkflx 
21. Najafabadi, S. S. (2012). Astronomical tourism (Astro-tourism) in Cebu, Philippines: Essential features in selected destinations and its complementing visitor attractions. In: International Conference on Trade, Tourism and Management (ICTTM 2012), December 21-22, 2012 Bangkok (Thailand), Conference Proceedings: 129-133. https://tinyurl.com/yxfl9blb

22. Pisarek, M.; Gargała-Polar, M.; Dudek, T. (2017). Astroturystyka w zainteresowaniu wybranych mieszkańców Województwa Podkarpackiego. Polish Journal for Sustainable Development, 21 (2): 1-6. http://doi.org/10.15584/ pjsd.2017.21.2.11

23. Priyatikanto, R.; Admiranto, A. G.; Putri, G. P.; Elyyani, E.; Maryam, S.; Suryana, N. (2019). Map of Sky Brightness over Greater Bandung and the Prospect of Astro-Tourism. Indonesian Journal of Geography, 51 (2): 190-198. https://doi. org/10.22146/ijg.43410

24. Soleimani, S.; Bruwer, J; Gross, M. J.; Lee, R. (2019). Astro-tourism conceptualisation as special-interest tourism (SIT) field: a phenomonological approach. Current Issues in Tourism, 22 (18): 2299-2314. https://doi.org/10.1080/13683 500.2018 .1444021

25. Tadić, M. (2016). Астрономија голим оком у масовном туризму. ГАасник Српског географског Аруштва, 96 (1): 127-144. https://www.ceeol.com/ search/article-detail? id=581442

26. Tobin, F. and Dunne, F. (2017), It's Written in the Stars - Exploring the Potential for Dark-Sky Tourism in South Kerry, in: Hanrahan, J. (Ed.). Tourism and Hospitality Research in Ireland, Entrepreneurs driving tourism and hospitality: 309-324. Ireland: School of Business and Social Science IT Sligo Ireland

27. Toivonen, A. (2017). Sustainable planning for space tourism. Matkailututkimus. 13 (1-2): 21-34. https://journal.fi/matkailututkimus/article/view/67850

28. Weaver, D. (2011). Celestial ecotourism: newhorizons in nature-based tourism, Journal of Ecotourism. 10 (1): 38-45. https://doi.org/10.1080/14724040903576116

29. Welch, D. and Dick, R. (2012). Dark-Sky Parks Abstract. In: Environmental Impact of Light Pollution and its Abatement - Special Report of the Journal of the Royal Astronomical Society of Canada: 30-32. The Royal Astronomical Society of Canada, December 2012. https://tinyurl.com/y43hbq5m

30. Yazar, S. (2018.). Bir Kırsal Turizm Çeşidi Olarak Astro-Turizm ve Balıkesir İlinin Astro-Turizm Potansiyelinin Belirlenmesi. International Journal of Social and Economic Sciences, 8 (2): 01-09. https://tinyurl.com/yy2d4vne

31. van Wyk-Jacobs, L. (2018). Astro-tourism as a catalyst for rural route development (Doctoral dissertation). University of Pretoria. https://repository.up.ac.za/ handle/2263/70036 


\section{Izvori}

1. http://www.ad-beskraj.hr/petrova-gora-prvi-hrvatski-park-tamnog-neba, (Pregledano 05.11.2020.)

2. http://www.archeoastronomy.org/downloads/starlightdeclarationc.pdf, (Pregledano 05.11.2020.)

3. www.astro.hr, (Pregledano 05.11.2020.)

4. www.astrotourism.com, (Pregledano 05.11.2020.)

5. www.astronomitaly.com, (Pregledano 05.11.2020.)

6. www.astronomskisavez.hr, (Pregledano 05.11.2020.)

7. https://www.astronomskisavez.hr/index.php/14-vijesti/351-petrova-gora-prvimedunarodni-park-tamnog-neba-u-hrvatskoj, (Pregledano 05.11.2020.)

8. http://www.astronomskisavez.hr/index.php/14-vijesti/359-hrvatska-dobila-josjedan-park-tamnog-neba, (Pregledano 05.11.2020.)

9. www.darksky.org, (Pregledano 05.11.2020.)

10. https://www.darksky.org/croatia-earns-first-international-dark-sky-place-atpetrova-gora-biljeg, (Pregledano 05.11.2020.)

11. http://www.darkskiesawareness.org/defense-declaration.php, (Pregledano 05.11.2020.)

12. https://www.fundacionstarlight.org/en/section/history/281.htm, (Pregledano 05.11.2020.)

13. https://fundacionstarlight.org/en/section/starlight-stellar-parks/301.html, (Pregledano 05.11.2020.)

14. https://www.h-alter.org/vijesti/proglasen-prvi-medjunarodni-park-tamnog-neba-u-hrvatskoj, (Pregledano 05.11.2020.)

15. https://hrturizam.hr/petrova-gora-prvi-medunarodni-park-tamnog-neba-u-hrvatskoj/, (Pregledano 05.11.2020.)

16. www.iac.es, (Pregledano 05.11.2020.)

17. https://issuu.com/pubcipriano/docs/starlightcommonheritage, (Pregledano 05.11.2020.)

18. www.naturaviva.hr, Pregledano 05.11.2020.

19. World atlas of the artificial night sky brightness, https://tinyurl.com/yxoqehof 


\title{
Astrotourism - In Search of New Spaces and Imagination in Tourism
}

\author{
Aleksandra Krajnović \\ University of Zadar, Department of Economics, Croatia \\ e-mail: akrajnov@unizd.hr
}

\begin{abstract}
This paper explores the concept and development of astrotourism as a new form of sustainable and responsible tourism that is developing rapidly in many countries around the world, with a special emphasis on certification in astrotourism. Two research hypotheses are set in the paper. First, there is a close correlation between the development of astrotourism as a new form of selective tourism and strengthening of the protection against light pollution, where the dark sky is a basic natural prerequisite for the development of this form of tourism. Second, certification in astrotourism is increasingly developing at the global and national levels in some countries. It has the purpose of the social and marketing affirmation of astrotourism, but also of raising public awareness of astronomy and the problem of light pollution. Both hypotheses were confirmed in the paper, based on a qualitative comparative analysis of three international certification projects in astrotourism. The paper deals specifically with the "Declaration on the Protection of the Night Sky and the Right to Starlight", the so-called La Palma or Starlight Declaration of 2007, which "started it all", and for the first time clearly proclaimed the right to a clear and dark, light-preserved sky as the right of humanity, which is also the year when the term astrotourism was first publicly introduced. The paper also gives an overview of the steps taken in the Republic of Croatia in this direction, with a special emphasis on the proclamation of two natural areas in the category of Dark Sky Park, as well as the adoption of legal regulations on combating light pollution. However, scientists have proven that Croatia has significant potential for the development of astrotourism, because its geographical area is still not completely light-polluted. The paper contributes to the theoretical framework in the field of astrotourism, confirming the correlation between the protection from light pollution and development of astrotourism, and sensitizing the scientific and general public to this issue, especially the problem of light pollution, as well as incentives for better valorization of astrotourism's potential. Republic of Croatia, based on the principles of sustainable development.
\end{abstract}

Key words: astrotourism, science and tourism, light pollution, Starlight Declaration, certificates in astrotourism, dark sky park. 